\title{
Understanding spatial and temporal patterns of human-elephant conflict in Assam, India
}

\author{
Scott Wilson, Tammy E. Davies, Nandita Hazarika \\ and ALEXANDRA ZIMMERMANN
}

\begin{abstract}
Large-scale forest encroachment in Assam, India, has led to increasing levels of human-elephant conflict. Conflict mitigation is a priority for the survival of Asian elephants Elephas maximus throughout Asia. We analysed a 3-year dataset of elephant occurrence and related instances of human-elephant conflict, from two sites in Assam, and explored the relationships between the various effects of elephants on human communities and factors influencing the spatial and temporal occurrence of these effects (proximity to water, refuge areas and villages, and human and crop density). The landscapes at both study sites have been transformed by forest loss, with large areas converted to agriculture. Remaining forest patches, which are mostly small, disconnected and degraded, as well as tea plantations, provide refuge areas for elephants as they move through the region. We found that crop depredation and property damage caused by elephants showed well-defined seasonal trends. They also showed a clear diurnal pattern, mostly occurring between 18.00 and 22.00. Small communities within $700 \mathrm{~m}$ of a refuge were most affected. In the management of human-elephant conflict in Assam we need to consider the refuge patches used by elephants as they move through the region, the peripheries of which are likely to be conflict hotspots. Small villages on the edges of refuges should be a priority for conflict mitigation assistance, with strategies taking into account seasonal and diurnal variation in elephant behaviour, as well as the socio-economic and cultural composition of communities.
\end{abstract}

Keywords Asian elephant, Assam, crop-raiding, Elephas maximus, human-elephant conflict, India, refuge, spatial analysis

SCOTT Wilson (Corresponding author) and ALEXANDRA ZimmermanN ${ }^{*}$ The North of England Zoological Society, Chester Zoo, Caughall Road, Chester, CH2 $1 \mathrm{LH}, \mathrm{UK}$.

E-mail s.wilson@chesterzoo.org

Tammy E. Davies St. Andrew's University, St. Andrew's, Fife, UK

NANDITA HAZARIKa EcoSystems-India, Guwahati, Assam, India

${ }^{*}$ Also at: Wildlife Conservation Research Unit, University of Oxford, Tubney, UK

Received 30 May 2012. Revision requested 22 November 2012.

Accepted 6 March 2013. First published online 7 November 2013.

\section{Introduction}

There is an ongoing decline in the number of Asian I elephants Elephas maximus in the wild, mainly as a result of habitat loss and fragmentation caused by expanding human populations and associated increasing demand for resources (Sukumar, 1989; Leimgruber et al., 2003). North-east India is one of the last remaining strongholds for the Asian elephant, with an estimated population of 9,000 (Project Elephant Synchronized Census, 2002), but in recent decades the region has experienced human population growth at significantly higher rates than the global average (Das, 2011; United Nations, 2011). In Assam this has resulted in rapid and large-scale agricultural expansion and associated forest loss and degradation. This has led to a significant reduction in forest cover, escalation of humanelephant conflict, and erosion of the region's traditional respect for elephants (Fernando et al., 2005).

Human-elephant conflict is a major threat to the future survival of elephants, particularly in rural agricultural regions where human populations continue to expand and encroach on habitat used by elephants (Hoare \& du Toit, 1999; Sitati et al., 2003). The consequences of elephant behaviour for communities are often tangible and can be devastating for individual farmers (Naughton-Treves \& Treves, 2005; Osei-Owusu \& Bakker, 2008). As a result elephants can elicit fear and anger in rural communities (Sitati, 2003; Parker et al., 2007), often leading to farmers persecuting elephants (Parker et al., 2007; Boominathan et al., 2008). Human-elephant conflict undermines support for elephant conservation and threatens the future of elephant populations outside protected areas.

The spatial relationship between elephants, people and associated socio-economic factors influences the occurrence and severity of human-elephant conflict. Globally, communities on the periphery of wildlife areas are often more susceptible to conflict with wildlife, which can be exacerbated by a low capacity to deal with the problem (Karanth, 2005). Government reports have estimated that $3,555 \mathrm{~km}^{2}$ of Assam's forests are encroached upon by illegal settlers, with $>$ 70,000 households (Department of Environment \& Forests, 2011), and that $>200$ million people in India are dependent on forests for their livelihoods (Forest Survey of India, 2009). Commonly, low-income marginal or immigrant communities settle near or within these natural areas (Treves, 2009). Such communities may lack government support and are limited in their financial capacity to absorb 


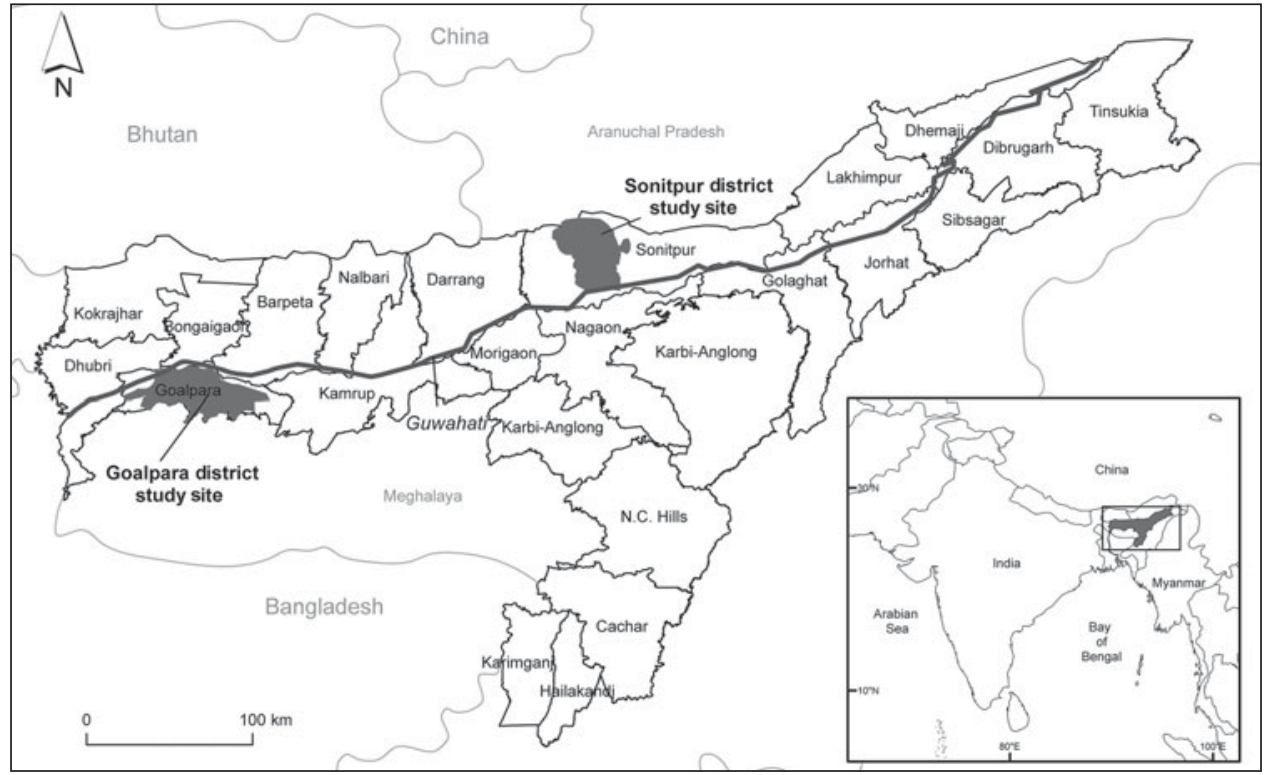

FIG. 1 Map of Assam showing the location of the Sonitpur and Goalpara study sites. The rectangle on the inset indicates the location of Assam in north-east India. wildlife-related losses (Nath \& Sukumar, 1998; Naughton et al., 1999). High levels of human-elephant conflict in Assam are therefore unsurprising, given the significant population of elephants in a state in which there has been major forest encroachment and that has one of the country's lowest per capita incomes. A 2012 census of the wild elephant population in Assam reported 5,620 elephants inhabiting national parks, wildlife sanctuaries and reserve forests (The Assam Tribune, 2012); this is $>10 \%$ of the estimated global wild Asian elephant population (Sukumar, 2003).

Mitigating human-elephant conflict is a conservation priority and empowering the local community to take responsibility for the problem is considered one of the most sustainable solutions (Osborn \& Parker, 2003). A community-centred approach provides opportunities to improve the attitudes of communities towards elephants and increases the potential of long-term conservation strategies such as habitat protection. To develop and direct effective community-led mitigation strategies it is vital to gain a thorough understanding of the human-elephant conflict problem on both a community and regional scale.

The development and improved accessibility of technologies such as remote sensing and geographical information systems (GIS) have increased the potential for the analysis of spatial and temporal patterns relating to wildlife management and research. Other studies of human-wildlife conflict, most commonly focused on elephants or large carnivores, have shown considerable spatial predictability in patterns of crop-raiding or depredation on livestock (Ahearn et al., 2001; Treves et al., 2004). However, spatial studies of human-elephant conflict, which to date have predominantly focused on African elephants Loxodonta africana, have produced mixed results. Hoare (1999a) did not identify any strong spatial correlates, Smith \& Kasiki
(1999) identified spatial correlates related to human and elephant density, and Sitati et al. (2003) found the occurrence of conflict and its intensity to be related to areas of cultivation and proximity to towns and roads.

Recent studies have found that human-elephant conflict usually occurs between dusk and dawn (Venkataraman et al., 2005), that crop-raiding is seasonal (Chiyo et al., 2005) and that conflict is generally highest in close proximity to protected areas (Parker \& Osborn, 2001). Spatial patterns of conflict with the Asian elephant, in contrast to the African elephant, have been relatively poorly studied. In Assam, recent studies have focused on forest loss in relation to human-elephant conflict levels (Chartier et al., 2011) and the efficacy of different mitigation methods (Fernando et al., 2008; Davies et al., 2011) and have made recommendations for improved understanding of the spatial factors influencing human-elephant conflict. Here we focus on the spatial and temporal patterns of human-elephant conflict in two conflict hotspots in Assam, with the aim of informing future mitigation and landscape management decisions.

\section{Study area}

Two sites were selected for data collection (Fig. 1), as part of the Assam Haathi Project, in districts that experience human-elephant conflict (Goalpara and Sonitpur). Records of elephant movement patterns in these districts were published by Choudbury (1999), who reported irregular and occasional north to south movement in the Sonitpur district and regular north to south movement in the Goalpara district.

Existing forest cover in both districts is dominated by moist deciduous forest, although both areas have been transformed by agricultural expansion and forest encroachment and contain a mosaic of land use. The production 
of Sali, or winter rice, dominates in both districts, with harvesting occurring between November and January. Two other rice varieties are also grown: Ahu rice (harvested between April and June) and Bodo rice (harvested in late June and early July).

The $729.6 \mathrm{~km}^{2}$ Sonitpur study site contains 181 villages, which have a mean population of 1,056 people. It borders the Brahmaputra River to the south and the Himalayan foothills to the north, with Nameri National Park to the north-east and Sonai-Rupai Reserve Forest and Wildlife Sanctuary to the north-west. The eastern and western borders of the study area are defined by the Bhareli and Gabharu rivers, respectively.

The Goalpara district is characterized by a flat plain with riverine beds. The $987 \mathrm{~km}^{2}$ study area contains 187 villages, which have a mean population of 1,650, and borders the Brahmaputra River to the north and the forested Garo Hills to the south. The eastern and western borders of the study site are defined by the Dudhnai and Jinjiram rivers, respectively.

\section{Methods}

\section{Data collection}

Data collection began in 2004 but here we analyse data collected between 1 January 2006 and 31 December 2008. To establish a reliable and independent reporting system (Hoare, 1999b) a team of 33 local community members were trained as field researchers to record data associated with any elephant activity within the study sites, including enumeration of any incidents of human-elephant conflict. This third-party enumeration reduced the problem of exaggeration of losses by the farmers themselves (Siex \& Struhsaker, 1999). The area of crop damage was estimated using paced distances, and this value was halved when crops had been trampled rather than eaten, because field observations indicated that roughly half of trampled crop survives. Each field researcher had a defined area of responsibility, and a network of researchers provided full coverage of each study site. Researchers visited all areas of elephant activity within their area of responsibility. The data collected included quantification of elephant-caused damage to crops, property or people, herd demographics (if known), and time and location of records. Each record related to an occurrence of elephants in a specific community (usually defined by village administrative boundaries) at a certain time. Multiple occurrences of elephants over a number of days in the same community resulted in separate records for each day. If an elephant herd was present in different localities on the same day a record for each community was created. If field researchers reached a site and elephants were no longer present, information was gathered through interviews with local villagers and field signs were recorded. All field records were collated by a regional coordinator before being cross-checked and imported to a geodatabase.

Data associated with elephant field records were spatially analysed in relation to other environmental variables: distance to the nearest refuge area, water body and village, and human population and crop density. These factors have been shown to influence human-elephant conflict (Nyhus et al., 2000; Parker \& Osborn, 2001; Sitati et al., 2005). Land-use data were derived from $15 \mathrm{~m}$ resolution 2008 ASTER satellite imagery that had undergone a supervised classification, and were verified by random sampling to be $>80 \%$ accurate. Land use was categorized as water, tea garden, forest, cropland, sand, homestead/human-dominated or scrubland. Based on comprehensive field records and observations the areas classified as forest (all types, including degraded) and tea gardens were reclassified as refuge areas. Refuge areas were defined as localities to which elephants retreated during the day. Elephants were generally undisturbed in such areas; if the areas were close to human habitation, elephant presence was usually tolerated.

Human population density was calculated using data recorded from village surveys. Crop density (percentage crop cover per $\mathrm{km}^{2}$ ) was calculated from a resampled $100 \mathrm{~m}$ resolution land-use raster map, with the value of each cell based on the number of surrounding $10 \times 10$ cells classified as cropland. For each record of elephant activity, the distances from the nearest refuge, water and village were calculated from the digitized data using GIS.

\section{Data analyses}

All spatial data used the projection WGS 1984 and UTM Zone $46 \mathrm{~N}$, and were analysed using ArcGIS v. 9.3 (ESRI, Redlands, USA) and the Geospatial Modelling Environment (Spatial Ecology LLC, Toronto, Canada). To account for environmental factors in areas outside but adjacent to the study sites that could potentially influence elephant activity within the study areas, a $10 \mathrm{~km}$ buffer zone was applied to all land-use data so that these adjacent areas were included in analyses. There were no elephant records for the buffer zone but factors such as water bodies, refuge areas and villages were included. The buffer was not applied over obvious physical barriers to elephant movement, such as the Brahmaputra River.

Initial data analysis compared human-elephant conflict across the two sites and over the 3-year study period. Conflict data were tabulated with the spatially associated values for distance to nearest refuge, water body and village, and human population and crop density. The relationships between human-elephant conflict and these variables were then explored spatially using GIS and statistically using Spearman's rank correlation. 

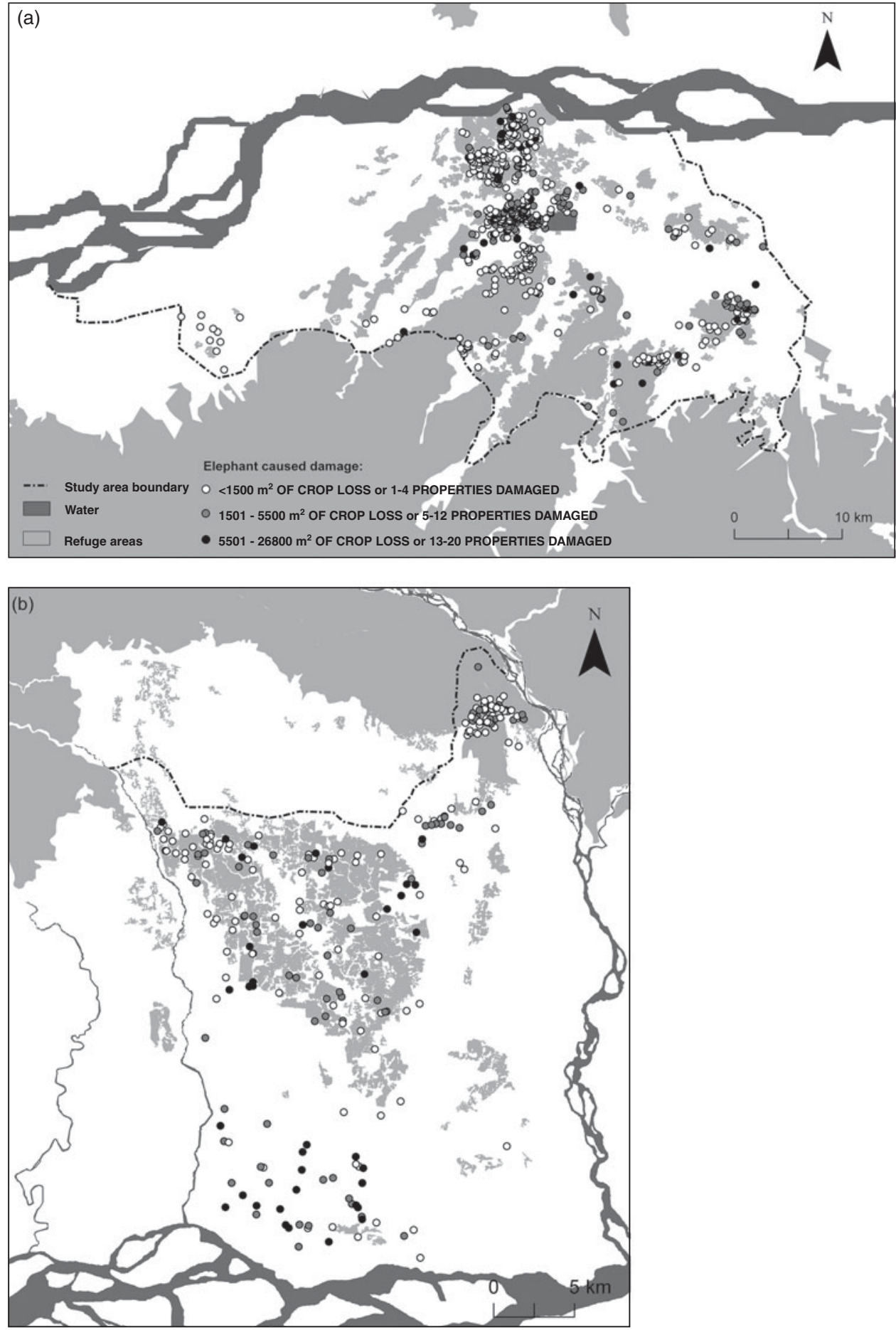

FIG. 2 Distribution of refuges and the occurrence of crop depredation and property damage by elephants at (a) the Goalpara study site, and (b) the Sonitpur study site.

\section{Results}

At Sonitpur significant areas of potential refuge for elephants were largely located outside the study area, within the bordering national parks to the north (Fig. 2b). At Goalpara the edge of the southern foothill forests is less regular, and potential areas of forest refuge protrude into the study area (Fig. 2a). This is reflected in the land-use characteristics of each study site: $24.1 \%$ of Goalpara and
$3 \%$ of Sonitpur are categorized as forest. In addition, $18.8 \%$ of the Sonitpur study site is classified as tea garden. These tea gardens are used extensively by elephants as refuge areas and mostly comprise commercial plantations of $342-782$ ha (Government of India, 2013); they are all situated in the north of the Sonitpur study site, where they are the dominant refuge area available to elephants. The Goalpara study site has no tea gardens. At both sites a significant proportion of land is used for agriculture $(20.6 \%$ in 
(a) 2006

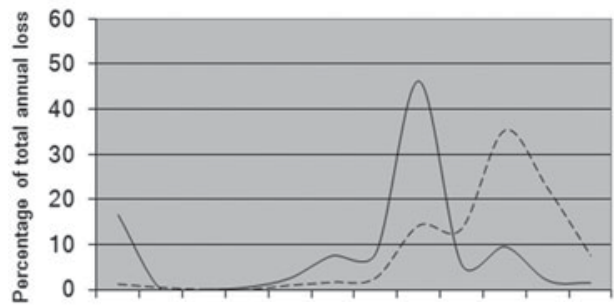

(b) 2007

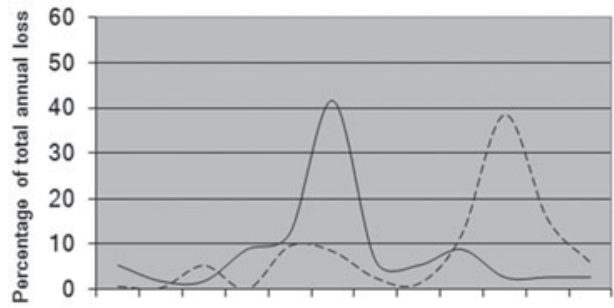

(c) 2008

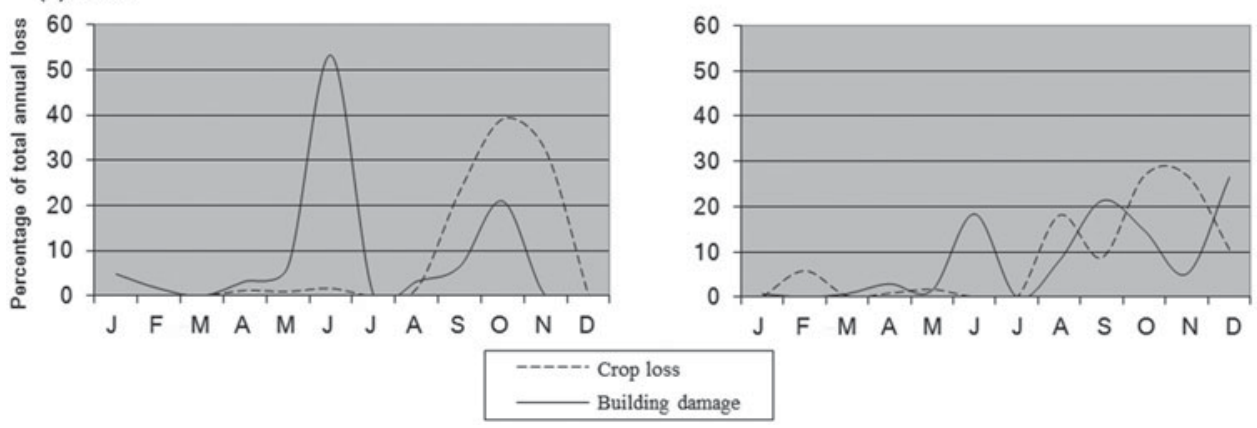

Sonitpur study site
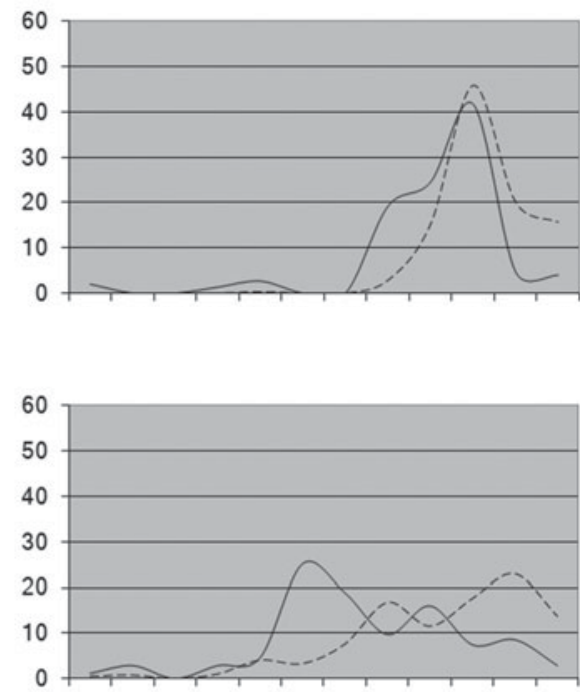

FIg. 3 Temporal trends in crop loss and property damage as a percentage of the total annual loss at the two study sites during (a) 2006, (b) 2007, and (c) 2008 .
Goalpara, 31.6\% in Sonitpur). Both study sites also have small, dispersed patches of state or privately owned forest, usually associated with villages, which are also classified as refuge areas; these are all $<0.5 \mathrm{~km}^{2}$.

Elephant movement follows a seasonal pattern at both study sites (Fig. 3), with elephants occurring annually. This is consistent with previous reports of movement patterns for the Goalpara district (Choudbury, 1999) but shows a shift in the movement pattern for the Sonitpur district compared with previously reported irregular and occasional elephant movement.

In total we recorded 1,561 incidents of human-elephant conflict (Sonitpur, 993; Goalpara, 568), and the scale and financial impact of these are shown in Table 1 . The most commonly reported form of human-elephant conflict was crop damage, followed by property damage. Fig. 2 shows the spatial distribution of refuge areas in relation to areas where crop and property damage by elephants were reported. There were too few records of injuries or fatalities to people or elephants to show any meaningful spatial or temporal patterns. The temporal patterns of crop and property damage are shown in Fig. 3, with both showing distinct seasonal peaks. In 2007 and 2008 property damage was most extensive between May and June and crop damage between August and December. This pattern differed in 2006 because of severe flooding in Assam, which impeded the movement of elephants into both study areas and also disrupted the usual agricultural calendar. There is a clear diurnal pattern to human-elephant conflict, with the majority of incidents at both sites occurring between 18.00 and 22.00 (Fig. 4). However, human-elephant conflict begins earlier at the Goalpara study site, with more conflict occurring between 16.00 and 18.00 compared to the Sonitpur site.

Using Spearman's rank correlations we identified several significant relationships between the various humanelephant conflict and environmental variables. Distance to refuge area was most commonly significantly correlated with other variables (Tables 2 \& 3); spatial analyses complemented these findings. We identified strong spatial relationships between refuge areas, elephant movement patterns and the occurrence and severity of human-elephant conflict.

At both study sites we identified a relationship between the distribution of people and of refuge areas: villages were 
TABLE 1 Quantification of the effects of human-elephant conflict during 2006-2008 in the Sonitpur and Goalpara districts of Assam (Fig. 1), and in total for both study sites, in terms of crop depredation, property damage, injuries and fatalities suffered by people, and injuries and fatalities suffered by elephants Elephas maximus.

\begin{tabular}{|c|c|c|c|}
\hline & Sonitpur & Goalpara & Total \\
\hline Area of crop depredation $\left(\mathrm{km}^{2}\right)$ & 1.81 & 1.24 & 3.05 \\
\hline $\begin{array}{l}\text { Financial losses as a result of } \\
\text { crop depredation (GBP) }\end{array}$ & 30,265 & 14,364 & 44,629 \\
\hline No. of properties damaged & 442 & 362 & 804 \\
\hline $\begin{array}{l}\text { Cost of damage to properties } \\
\text { (GBP) }\end{array}$ & 15,042 & 14,973 & 30,015 \\
\hline No. of people injured & 14 & 8 & 22 \\
\hline No. of human fatalities & 7 & 7 & 14 \\
\hline No. of elephants injured & 5 & 7 & 12 \\
\hline No. of elephant fatalities & 0 & 0 & 0 \\
\hline
\end{tabular}

predominantly located close to refuge areas. At the Goalpara study site $75 \%$ of all villages were within $1 \mathrm{~km}$ of a refuge area and $50 \%$ were within $400 \mathrm{~m}$. Similarly at the Sonitpur study site $75 \%$ of villages were within $900 \mathrm{~m}$ of a refuge and $50 \%$ were within $500 \mathrm{~m}$. The spatial patterns and scale of human-elephant conflict showed an even stronger relationship to refuge, with $90 \%$ of all recorded parameters related to human-elephant conflict occurring within $700 \mathrm{~m}$ of a refuge area. The only exception to this was property damage at the Goalpara study site, where $50 \%$ of incidents occurred within $200 \mathrm{~m}$ of a refuge area and 90\% within $1.48 \mathrm{~km}$. Seemingly contradictory to these findings is the strong positive correlation at both study sites between the areas of crop loss as a result of elephant depredation and the distance to the nearest refuge area, indicating that the area of crop damage per incident increases as crop depredation occurs further from refuge areas.

In Goalpara the mean herd size was $18.8 \pm$ SD 9.48 (range 1-50), composed of 1.6 adult males, 3.1 adult females, 0.6 juveniles, 4.0 calves, and 3.0 individuals of unknown age or sex. At the Sonitpur study site the mean herd size was 11.1 \pm SD 17.2 (range 1-130), composed of 0.5 adult males, 0.4 adult females, 0.6 calves, and 8.0 individuals of unknown age or sex.

\section{Discussion}

In landscapes that have been transformed by anthropogenic influences such as expansion of agriculture, isolated populations of species often occur, persisting largely in remnants of suitable habitat. Populations of wide-ranging species such as elephants, however, may continue to move through such landscape mosaics, and their movement patterns are often influenced by the spatial distribution and suitability of remaining refuge areas. Our findings indicate relationships between refuge area distribution, elephant movement

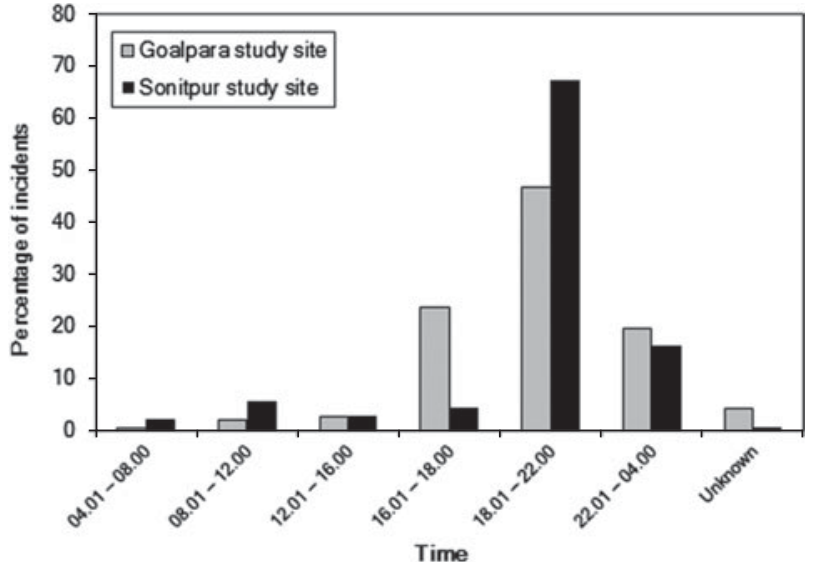

FIG. 4 Diurnal pattern of incidents of crop loss or property damage caused by elephants, showing the percentage of incidents that occurred during different time periods.

patterns and the occurrence and severity of human-elephant conflict, with communities adjacent to refuge areas being most affected by human-elephant conflict. There is also evidence of temporal variance, both seasonal and diurnal, of conflict, as well as potential variance in the severity and nature of the conflict as a result of cultural and socioeconomic differences in communities. These factors all have implications for human-elephant conflict management.

Water availability often influences the movement of animals but we found no correlation between water distribution and any of the human-elephant conflict parameters. The main movement of elephants at both study sites occurs between protected areas and the Brahmaputra River through a highly transformed human-dominated landscape but where water is widely available in rivers and numerous water bodies. Water influences human-population density and crop density, as expected for rice-based agricultural systems, but it is the distribution of refuge areas that influenced elephant movement and thus human-elephant conflict patterns in this study.

The nature, as well as the distribution, of refuge areas may influence human-elephant conflict. The refuge areas at our study sites were generally of a low value in terms of food availability and nutritional quality for elephants. Remaining forest patches were commonly state or community owned, planted with commercial species, and with low levels of biodiversity. Although tea gardens provide important refuge areas, they contain little or no food resources for elephants. We recorded no incidents of elephants consuming tea. Demographic data showed that incidents of human-elephant conflict tended to involve small herds containing sub-adult individuals and calves. This could be indicative of a nutritional necessity for crop depredation and the raiding of granaries. Crop-raiding behaviours in particular have more commonly been recorded amongst male elephants in other regions and attributed to a high-risk foraging strategy employed to gain a breeding advantage 
TABLE 2 Spearman's rank correlations* between factors potentially influencing the occurrence and scale of human-elephant conflict at the Sonitpur study site.

\begin{tabular}{|c|c|c|c|c|c|c|c|c|c|}
\hline & $\begin{array}{l}\text { Distance } \\
\text { to refuge }\end{array}$ & $\begin{array}{l}\text { Distance } \\
\text { to water }\end{array}$ & $\begin{array}{l}\text { Human } \\
\text { population } \\
\text { density }\end{array}$ & $\begin{array}{l}\text { Crop } \\
\text { density }\end{array}$ & $\begin{array}{l}\text { Distance } \\
\text { to nearest } \\
\text { village }\end{array}$ & $\begin{array}{l}\text { Crop loss } \\
\text { (area) }\end{array}$ & $\begin{array}{l}\text { Human } \\
\text { death or } \\
\text { injury }\end{array}$ & $\begin{array}{l}\text { Elephant } \\
\text { death or } \\
\text { injury }\end{array}$ & $\begin{array}{l}\text { Property } \\
\text { damage } \\
\text { (count) }\end{array}$ \\
\hline \multicolumn{10}{|l|}{ Distance to refuge } \\
\hline Distance to water & --- & & & & & & & & \\
\hline Human population density & ++ & NS & & & & & & & \\
\hline Crop density & +++ & -- & +++ & & & & & & \\
\hline Distance to nearest village & NS & +++ & --- & --- & & & & & \\
\hline Crop loss (area) & +++ & --- & NS & +++ & -- & & & & \\
\hline Human death or injury & NS & NS & NS & NS & NS & NS & & & \\
\hline Elephant death or injury & - & NS & NS & NS & NS & NS & NS & & \\
\hline Property damage (count) & -- & + & NS & NS & NS & --- & +++ & NS & \\
\hline
\end{tabular}

${ }^{*}+$, positive correlation $(\mathrm{P}<0.05) ;++$, positive correlation $(\mathrm{P}<0.01) ;+++$, positive correlation $(\mathrm{P}<0.001)$; - , negative correlation $(\mathrm{P}<0.001)$ -- , negative correlation $(\mathrm{P}<0.01) ;---$, negative correlation $(\mathrm{P}<0.05)$; NS, no significant correlation

TABLE 3 Spearman's rank correlations ${ }^{\star}$ between factors potentially influencing the occurrence and scale of human-elephant conflict at the Goalpara study site.

\begin{tabular}{|c|c|c|c|c|c|c|c|c|c|}
\hline & $\begin{array}{l}\text { Distance } \\
\text { to refuge }\end{array}$ & $\begin{array}{l}\text { Distance } \\
\text { to water }\end{array}$ & $\begin{array}{l}\text { Human } \\
\text { population } \\
\text { density }\end{array}$ & $\begin{array}{l}\text { Crop } \\
\text { density }\end{array}$ & $\begin{array}{l}\text { Distance } \\
\text { to nearest } \\
\text { village }\end{array}$ & $\begin{array}{l}\text { Crop loss } \\
\text { (area) }\end{array}$ & $\begin{array}{l}\text { Human } \\
\text { death or } \\
\text { injury }\end{array}$ & $\begin{array}{l}\text { Elephant } \\
\text { death or } \\
\text { injury }\end{array}$ & $\begin{array}{l}\text { Property } \\
\text { damage } \\
\text { (count) }\end{array}$ \\
\hline \multicolumn{10}{|l|}{ Distance to refuge } \\
\hline Distance to water & --- & & & & & & & & \\
\hline Human population density & +++ & --- & & & & & & & \\
\hline Crop density & +++ & --- & +++ & & & & & & \\
\hline Distance to nearest village & +++ & --- & NS & +++ & & & & & \\
\hline Crop loss (area) & +++ & NS & NS & +++ & NS & & & & \\
\hline Human death or injury & NS & NS & NS & NS & NS & NS & & & \\
\hline Elephant death or injury & + & NS & NS & NS & NS & NS & ++ & & \\
\hline Property damage (count) & +++ & NS & NS & +++ & NS & +++ & +++ & +++ & \\
\hline
\end{tabular}

${ }^{*}+$, positive correlation $(\mathrm{P}<0.05) ;++$, positive correlation $(\mathrm{P}<0.01) ;+++$, positive correlation $(\mathrm{P}<0.001)$; - , negative correlation $(\mathrm{P}<0.001)$; -- , negative correlation $(\mathrm{P}<0.01) ;---$, negative correlation $(\mathrm{P}<0.05)$; NS, no significant correlation

(Sukumar \& Gadgil, 1988; Sukumar, 1991). The drivers for depredation of crops and granary stores by elephants require further investigation but these results may indicate that mitigation methods themselves (the protection of crops and granaries), though removing the direct risks to people and elephants inherent in human-elephant conflict situations, may place nutritional stress on elephant populations. Management strategies should consider fostering attitudes of acceptance towards low-level crop loss rather than attempting to negate all elephant crop depredation, and should focus on the management of refuge areas that have a food resource value for elephants.

Our findings indicate that the primary function of refuge areas for elephants is not nutritional but to enable elephants to avoid contact, and conflict, with people. Refuge areas may also have a physiological role, such as the provision of shade to assist thermal regulation (Kinahan et al., 2007). Elephants leave the refuge areas in the evening, which would fit with both of the above suggested functions, and humanelephant conflict occurs mostly between evening and dawn. This diurnal resting pattern has been observed in other elephant populations experiencing conflict with humans (Venkataraman et al., 2005). Elephants at the Goalpara study site become active earlier and anecdotal field reports suggest that this difference in behaviour is because of variations in how communities respond to elephants. At the Sonitpur study site, particularly around the tea gardens, communities respond more quickly and aggressively to elephants emerging from refuges, thus limiting crop and property damage. The delayed occurrence of humanelephant conflict at the Sonitpur study site may be a result of the proactive approach of communities to protecting their crops and properties, or it may be because elephants emerge from refuge areas later, when they feel more secure. The tea garden communities are largely composed of immigrant labourers, and such communities may not have 
experience of dealing with elephants or share the local tolerant attitude towards elephants, which is influenced by religion. These communities live on the edge of tea gardens, which function as refuge areas, and are therefore situated in high-risk areas for human-elephant conflict. Their more aggressive nature towards elephants, combined with a greater occurrence of property damage compared to crop depredation (as they are primarily labourers rather than farmers), suggests that they pose a greater physical threat to elephants. These cultural variances between communities, both in terms of attitudes towards elephants and the type of conflict experienced, need to be considered when engaging communities in conservation.

For all communities those most affected by humanelephant conflict are situated within $700 \mathrm{~m}$ of a refuge area. These communities tend to have smaller than average populations, with poorly protected homesteads and no electricity. They are commonly dependent on small-scale subsistence agriculture and live in areas of less than optimal growing conditions. This finding is supported by other studies that have also found that conflict with elephants increases in intensity with proximity to forests (Kiiru, 1995; Nath \& Sukumar, 1998; Naughton et al., 1999; Nyhus et al., 2000; Lahkar et al., 2007; Riddle, 2007). Sukumar (1989) found that herds tended not to venture further than $1 \mathrm{~km}$ from a forest boundary.

However, not all communities in areas of low crop and human density suffer from human-elephant conflict, and there is a lack of correlation between these factors in our results. This indicates that there are several areas of low human population density where elephants are present but where there is no significant conflict. These communities are not in close proximity to a refuge area but are in areas through which elephants travel between refuges. There may also be an increased likelihood of communities that have been targeted by elephants previously being targeted again in future raids (Sitati et al., 2005; Stewart-Cox \& Ritthirat, 2007).We found that communities in areas of higher crop density, which are further from refuges, suffer significantly larger areas of crop loss per incident of elephant depredation than communities close to refuges. However, communities near refuge areas are subject to a much higher frequency of crop damage by elephants. This may indicate different crop depredation behaviours dependent upon access to refuge areas. Field observations indicate that elephants often employ a hit-and-run strategy, in which refuge areas are used as a safe retreat. In areas of higher crop density, which tend to be further from refuge areas, the increased area of crop damage per incident may be a direct result of the higher density of crops, which facilitates the consumption of more crops in a short time. Areas of high crop density, perhaps indicating more commercial rather than subsistence plots, may also be more difficult to protect, and elephants may feel more secure and remain for longer periods. These results warn against misinterpreting parameters such as area of crop loss when trying to quantify human-elephant conflict. Small losses may have a disproportional effect on a subsistence farmer. Similarly, minor but frequent instances of elephants entering villages and damaging property may have much larger psychological and economic effect than major but infrequent occurrences, particularly in remote, marginalized communities.

Whereas spatial patterns of elephant movement and human-elephant conflict are influenced by the location of refuge areas, seasonal patterns are more strongly influenced by the agricultural calendar. Crop depredation peaks between August and December, when the dominant Sali rice crop is reaching maturity or is ready for harvest. This period also coincides with an increase in property damage, as elephants target stored crops. Sali rice is the major staple subsistence crop and the primary source of income for most rural families in the study areas, and crop depredation by elephants is the most common trigger of human-elephant conflict in Assam and throughout most of India (Lenin \& Sukumar, 2011). There is a smaller seasonal peak of crop damage by elephants between May and July, when the Ahu and Bodo varieties of rice reach maturity, although crop losses are lower during this period. This may be a reflection of the lower availability of these crops compared to the more widely grown Sali rice. Property damage peaks during this period, when it is likely that granaries will contain not only newly harvested crops but also remains of the Sali harvest, thus providing a more beneficial target for foraging elephants. There is a significant correlation between the occurrence of injuries and fatalities among villagers and periods of increased property damage, when elephants are entering villages. The results of this study could be used to inform strategies to enable communities to persist alongside elephants, and to provide guidance for landscape-scale management that will help sustain elephant populations. Elephant movements are influenced by the location of refuge areas, and manipulation of such refuge areas could be used to manage where elephants and communities come into contact. Large-scale projects to create corridors for elephant movement are possible with sufficient stakeholder involvement but when this involves rewilding or relocation of human populations it can be politically controversial and expensive. Corridors of tolerance may be a more feasible alternative, where communities have sufficient support and capacity to mitigate and tolerate the degree of elephant-related loss incurred.

At a community scale an understanding of the spatial and temporal patterns of human-elephant conflict is necessary for effective elephant conservation but must be combined with an understanding of cultural and socioeconomic influences. Marginalized communities close to refuge areas are a priority for assistance but mitigation and community engagement methods will need to be 
tailored to specific communities and sufficiently dynamic to cope with seasonal variations in conflict situations. Effective mitigation will increase tolerance towards elephants and reduce the risk of aggressive retaliation. Community engagement can also facilitate better management of negative effects on existing refuge areas, such as encroachment or illegal wood harvesting, and proactive measures to increase the quality and quantity of available refuge areas, such as reforestation projects. Crop losses as a result of depredation by elephants can be reduced by using solar electric fences or spotlights (Davies et al., 2011) but protection of granaries should also be a strong consideration, particularly at times of high risk.

Alternative livelihoods should also be a focus of community-based conservation, removing dependence on crops susceptible to depredation. Cash crops such as chilli, turmeric and ginger, which elephants do not consume, can diversify the harvesting periods and mitigate the risk of elephant depredation.

Each community's requirements are different, but this study shows that temporal and spatial analysis, when combined with an understanding of culture, socioeconomics and attitudes, can provide valuable information for conservation initiatives at both community and landscape scales.

The Assam Haathi Project has now expanded throughout Assam. Selection of new project villages has been greatly aided by spatial analysis of elephant movements and conflict, with particular attention to the refuge areas utilized by, and influencing the behaviour of, local elephant populations. A comprehensive community engagement process with all new project villages continues to be the first and most critical component of the conflict mitigation process.

\section{Acknowledgements}

This work was conducted by the Assam Haathi Project (www.assamhaathiproject.org), which is a project of the North of England Zoological Society (Chester Zoo) and EcoSystems-India. The project was funded by the UK government's Darwin Initiative and Chester Zoo. We are thankful to the following field monitors who assisted with data collection: Ajoy Kumar Dey, Bapkon Mili, Biplab Kumar Sundi, Birbal Limbu, Dhan Das, Dipankar Bora, Dipu Borah, Jayanta Kumar Nath, Kartik Koch, Narottam Sahani, Narayan Nath, Nichendra Nath, Raju Bagh, Rana Udia, Rudra Chetra, Sawan Tanti, Brillian Chandra Marak, Bhagabat Rabha, Devananda Rabha, Dibyajyoti Rabha, Dimbeswar Nath, Dugdha Nath, Dwipen Rabha, Kushal Nath, Rubul Rabha and Subhash Rabha. We are also grateful for coordination assistance and advice from Joydeep Chakrabarty, Bhaben Hazarika, Anjan Baruah, Lakhi Kumar Nath, Anjan Kumar Nath, Ripunjoy Nath, Apurba Basumatary, Dhruba Jyoti Das, Parag Jyoti Deka and Goutam Narayan of EcoSystems-India, Evette Astbury and Sam Earle of Chester Zoo, and Lucy Tallents of WildCru, Oxford University.

\section{References}

Ahearn, S.C., Smith, J.L.D., Joshi, A.R. \& Ding, J. (2001) TIGMOD: an individual-based spatially explicit model for simulating tiger/ human interaction in multiple use forests. Ecological Modelling, 140, 81-97.

Boominathan, D., Mohanraj, N., Aziz, T. \& Desai, A. (2008) Management of the Asian Elephant in the Nilgris and Eastern Ghats: Human-Elephant Conflict in Somwarpet Subdivision (Madikeri Forest Division). WWF AREAS, Kathmandu, Nepal.

Central Statistics Office (2010) S.I. No. 1-32 Statement: Cross State Domestic Product at Current Prices. Directorate of Economics and Statistics of Respective State Governments and for All-India, Delhi.

Chartier, L., Zimmermann, A. \& Ladle, R. (2011) Habitat loss and human-elephant conflict: does a critical threshold exist? Oryx, 45, 528-533.

Chiyo, P.I., Cochrane, E.P., Naughton, L. \& Basuta, G.I. (2005) Temporal patterns of crop-raiding by elephants: a response to changes in forage quality or crop availability? African Journal of Ecology, 43, 48-55.

Choudbury, A. (1999) Status and conservation of the Asian elephant Elephas maximus in north-eastern India. Mammal Review, 29, 141-173.

D As, K.C. (2009) Assam Land and People. Commerce College, Guwahati, India.

D As, R.K. (2011) Census of India 2011: Provisional Population Totals Paper 1 of 2011, Assam Series 1. Http://censusindia.gov.in/2011prov-results/data_files/india/paper_contentsetc.pdf [accessed 7 February 2013].

Davies, T.E., Wilson, S., Hazarika, N., Chakrabarty, J., Das, D., Hodgson, D.J. \& Zimmerman, A. (2011) Effectiveness of intervention methods against crop-raiding elephants. Conservation Letters, 4, 346-354.

Department of Environment \& Forests, Government of Assam (2011) Assam Forests at a Glance. Government of Assam. Http://www.assamforest.in/forestGlance/assamForest_glance.php [accessed 25 August 2011].

Fernando, P., Wikramanayake, E., Weerakoon, D., Jayasinghe, L.K.A., Gunawardene, M. \& JanaKa, H.K. (2005) Perceptions and patterns of human-elephant conflict in old and new settlements in Sri Lanka: insights for mitigation and management. Biodiversity Conservation, 14, 2465-2481.

Fernando, P., Kumar, A.M., Williams, C., Wikramanayake, E., Aziz, T. \& Sigh, M. (2008) Review of Human-Elephant Conflict Mitigation Methods Practiced in South Asia. AREAS Technical Support Document Submitted to World Bank. WWF-World Wide Fund for Nature, Kathmandu, Nepal.

Forest Survey of India (2009) State of the Forest Report 2009. Ministry of Environment and Forest, Government of India, Dehradun, India.

Government of India (2013) List of Tea Gardens in the Sonitpur District. Http://sonitpur.gov.in/list_of_tea_gardens.htm [accessed 7 December 2012].

Hoare, R.E. (1999a) Determinants of human-elephant conflict in a land-use mosaic. Journal of Applied Ecology, 36, 689-700.

Hoare, R.E. (1999b) A Standardized Data Collection and Analysis Protocol for Human-Elephant Conflict Situation in Africa. IUCN African Elephant Specialist Group, Nairobi, Kenya. 
Hoare, R.E. \& DU Tiot, J.T. (1999) Coexistence between people and elephants in African savannas. Conservation Biology, 13, 633-639.

Karanth, K.K. (2005) Addressing relocation and livelihood concerns: Bhadra wildlife sanctuary. Economic \& Political Weekly, 40, 4809-4811.

KiIRU, W. (1995) The current status of human-elephant conflict in Kenya. Pachyderm, 19, 15-19.

Kinahan, A.A., Pimm, S.L. \& Van Aarde, R.J. (2007) Ambient temperature as a determinant of landscape use in the savanna elephant, Loxodonta africana. Journal of Thermal Biology, 32, 47-58.

Lahkar, B.P., Das, J.P., Nath, N.K., Dey, S., Brahma, N. \& SARma, P.K. (2007) A Study of Habitat Utilization Patterns of Asian Elephant Elephas Maximus and Current Status of Human Elephant Conflict in Manas National Park within Chirang-Ripu Elephant Reserve, Assam. A Technical Report Prepared by Aaranyak.

Leimgruber, P., Gagon, J.B., Wemmer, C., Kelly, D.S., Songer, M.A. \& Selig, E.R. (2003) Fragmentation of Asia's remaining wildlands: implications for Asian elephant conservation. Animal Conservation, 6, 347-359.

Lenin, J. \& Sukumar, R. (2011) Action Plan for the Mitigation of Human-Elephant Conflict in India. Asian Nature Conservation Foundation, Bangalore, India.

Nath, C.D. \& Sukumar, R. (1998) Elephant-Human Conflict in Kodagu: Southern India. Asian Elephant Research and Conservation Centre, Bangalore, India.

Naughton, L., Rose, R. \& Treves, A. (1999) The Social Dimensions of Human-Elephants Conflict in Africa: A literature Review and Case Studies from Uganda and Cameroon. IUCN/SSC African Elephant Specialist Group, Nairobi, Kenya.

Naughton-Treves, L. \& Treves, A. (2005) Socio-ecological factors shaping local support for wildlife: crop-raiding by elephants and other wildlife in Africa. In People and Wildlife: Conflict or Coexistence (eds R. Woodroffe, S. Thirgood \& A. Rabinowitz), pp. 252-277. Cambridge University Press, New York, USA.

Nyhus, P.J., Tilson, R. \& Suminato, R.T. (2000) Crop-raiding elephants and conservation implications at Way Kambas National Park, Sumatra, Indonesia. Oryx, 34, 262-274.

Osborn, F.V. \& PARKer, G.E. (2003) Towards an integrated approach for reducing the conflict between elephants and people: a review of current research. Oryx, 37, 1-5.

Osei-Owusu, Y. \& Bakker, L. (2008) Human-Wildlife-Conflict: Elephant Technical Manual. Food and Agricultural Organization of the United Nations, Rome, Italy.

Parker, G.E. \& Osborn, F.V. (2001) Dual season crop damage by elephants in the Eastern Zambezi Valley, Zimbabwe. Pachyderm, $30,49-56$.

Parker, G.E., Osborn, F.V., Hoare, R.E. \& Niskanen, L.S. (eds) (2007) Human-Elephant Conflict Mitigation: A Training Course for Community-Based Approaches in Africa. Participant's Manual. Elephant Pepper Development Trust, Livingstone, Zambia and IUCN/SSC AfESG, Nairobi, Kenya.

Project Elephant Synchronized Census (2002) Asian Nature Conservation Foundation. Http://www.asiannature.org/resources/ statistics.htm [accessed 27 November 2012].

Riddle, H. (2007) Elephant response units (ERU). Gajah, 26, 47-53. SIEX, K.S. \& STRUHSAKER, T.T. (1999) Colobus monkeys and coconuts: a study of perceived human-wildlife conflicts. Journal of Applied Ecology, 36, 1009-1020.
Sit ati, N.W. (2003) Human-Elephant conflict in the Maasai Mara dispersal areas of Transmara District. PhD thesis, University of Kent, Canterbury, UK.

Sitati, N.W., Walpole, M.J., Smith, R.J. \& Leader-Williams, N. (2003) Predicting spatial aspects of human-elephant conflict. Journal of Applied Ecology, 40, 667-677.

Sitati, N.W., Walpole, M.J. \& Leader-Williams, N. (2005) Factors affecting susceptibility of farms to crop-raiding by African elephants: using predictive model to mitigate conflict. Journal of Applied Ecology, 42, 1175-1182.

Smith, R.J. \& KasiKi, S. (1999) A spatial analysis of human-elephant conflict in the Tsavo Ecosystem, Kenya. AfESG Report. IUCN/SSC, Gland, Switzerland.

Stewart-Cox, B. \& Ritthirat, J. (2007) Mitigating humanelephant conflict in Asia: a new initiative in Thailand. In Mitigating Human-Elephant Conflict: Case Studies from Africa and Asia. (eds Walpole, M. \& Linkie, M.) pp 13-22. Fauna \& Flora International, Cambridge, UK.

Sukumar, R. (1989) The Asian Elephant: Ecology and Management. Oxford University Press, Cambridge, UK.

SuKumar, R. (1991) The management of large mammals in relation to male strategies and conflict with people. Biological Conservation, 55, 93-102.

Sukumar, R. (2003) The Living Elephants: Evolutionary Ecology, Behaviour, and Conservation. Oxford University Press, Oxford, UK.

Sukumar, R. \& Gadgil, M. (1988) Male-female differences in foraging on crops by Asian elephants. Animal Behaviour, 36, 1233-1255.

The Assam Tribune (2012). Elephant population on the rise: Census report. Http://www.assamtribune.com/scripts/detailsnew.asp? id=mar3112/stateo 6 [accessed 7 February 2013].

Treves, A. (2009) The human dimensions of conflicts with wildlife around protected areas. In Wildlife and Society: The Science of Human Dimensions (eds M.J. Manfredo, J.J. Vaske, P.J. Brown, D.J. Decker \& E.A. Duke), pp. 214-228. Islands Press, Washington, DC, USA.

Treves, A., Naughton-Treves, L., Harper, E.K., Mladenoff, D. J., Rose, R.A., Sickley, T.A. \& Wydeven, A.P. (2004) Predicting human-carnivore conflict: a spatial model derived from 25 years of data on wolf predation on livestock. Conservation Biology, 18, 114-125.

United Nations, Department of Economic and Social Affairs, Population Division (2011) World Population Prospects: The 2010 Revision. CD-ROM ed.

Venkataraman, A.B., SaAndeep, R., Baskaran, R., Roy, M., Madhivanan, A. \& Sukumar, R. (2005) Using satellite telemetry to mitigate elephant-human conflict: an experiment in northern West Bengal, India. Current Science (Bangalore), $88,1827-1831$

\section{Biographical sketches}

Scott Wilson is the conservation officer at Chester Zoo, coordinating the zoo's field conservation activities (www.chesterzoo. org). He assisted Alexandra Zimmermann in developing the Zoo's Assam Haathi Project (AHP) in 2004. TAmmy Davies worked as a conservation researcher for the AHP and is currently studying sustainable livelihoods in the Solomon Islands. NANDita HAZARIKA manages the AHP in Assam, where she also works on a variety of sustainability projects and with the Pygmy Hog Conservation Programme. Alexandra Zimmermann is the senior conservation scientist at Chester Zoo and is currently researching conflict patterns between jaguars and people. 